\title{
ANALYSIS OF RAIL PROFILE 610 E1 JOINTS WELDED BY MEANS OF MOBILE RAIL WELDING MACHINE
}

\author{
Pavel Gavrilov, Viktor Ivanov \\ Riga Technical University, Latvia \\ pavels.gavrilovs@rtu.lv, viktori4301187@inbox.lv
}

\begin{abstract}
An idea to write this article emerged from the statistics of tracing defects of joints welded with a mobile rail welding machine type No 4 in the Latvian railway during the years of 2014, 2015, 2016 and 2017. The article will discuss a study of the welded joints of rail profile $60 \mathrm{E} 1$, often used both in main line tracks and branch lines of the Latvian railway. The study includes an analysis of defects in the welded rail profile $60 \mathrm{E} 1$ joints in the Latvian railway in eight sections of the line. A question emerges regarding the quality of joints fixed by flash-butt welding by means of a mobile rail welding machine. Once the metal hardness, chemical composition and structure of the rail steel are determined, the quality of flash-butt welding processed joints by means of the mobile rail welding machine type No 4 will be established. The study process comprises four phases. The first phase, determination of Brinell hardness by means of the modern device "Tinius O Olsen" Firmware Version 1.07, FH - 31 Series. The obtained results must be compared with data provided by the manufacturing plant Nizhniy Tagyl. The second phase, determination of the chemical structure of the welded joint of 60 E1 rail steel (in top, web, base) by means of the optical emission spectrometer "PMI - Master PRO". The obtained data must be compared with the manufacturer's data. The third phase, determination of rail steel structure. To draw the main conclusions regarding the rail steel of welded joints by means of the mobile rail welding machine type No 4 . The fourth phase, drawing of key conclusions and opinion regarding the quality of joints processed with the flash-butt welding technique by means of the mobile rail welding machine type No 4 .
\end{abstract}

Keywords: statistics, defect, rail, type, quality.

\section{Introduction}

Mobile rail welding machines (type No 4) are widely used to weld and repair the rails of the Latvian railway. For now 3 mobile rail welding machines type No 4 are operated in the Latvian railway. Mobile rail welding machine type No 4 is used to conduct the electric flash-butt welding of track rails. The machine can weld both rails situated on tracks, where the machine actually moves, and the rails put either inside or outside the gauge at $2600 \mathrm{~mm}$ distance from that track. Section of rails to be welded is 6400-10000 $\mathrm{mm}$. The machines are equipped with modern welding equipment, i.e. suspended welding heads K-900A, K-351A1.

Experience of operation on continuously welded rail in Latvian and foreign railways reveals both its high technical and economic efficiency and the "weak link" of this progressive construction of track superstructure, namely the balancing length of rails. Due to their joints one can see a dynamic impact of the rolling stock on the track, if compared to the middle part of rail length; one can also see earlier emergence of faults, intense permanent deformations. It results in an increased functional loss of rails, clamps, reinforced concrete sleepers, formation of pumpings. Specialists from different scientific research institutes (Central Scientific Research Textile Institute (CSRTI), Metallurgy Institute UrO RAN, Central Scientific Research Metallurgy and Materials Institute, Russian National Scientific Research Metallurgy Heat Technology Institute (RNSRMHTI) have contributed a lot of effort to improve the balancing rail lengths [5]. Reduction in the number of balancing lengths is in proportion to increasing the run of the rail lengths. By increasing the average run of rail length up to $1,500 \mathrm{~m}$, one can cut the number of balancing rail lengths by more than $60 \%$; if the run is increased to $5,000 \mathrm{~m}$, the decrease of balancing rail lengths augments by another $20-25 \%$. The reason why some time ago Latvia and many other countries chose to extend the continuously welded rails is an effort to get rid of joints. When choosing a run consisting of continuous welded rails up to a block length or running line, one cannot do without the most modern welding technologies, allowing to create continuous running surface (especially on high-speed tracks), and also to weld the crossing pieces of continuously welded rail.

Currently on railways of the Republic of Latvia the following types of welding were identified:

- flash-butt welding;

- enclosed arc welding;

- thermic welding. 
Usually when welding the continuously welded rails to form long or super long continuously welded rails, two welding types are used: alumino-thermic welding and electric contact welding.

Various types of rail welding considerably differ in terms of their technical and economical features. The most important indicator is: mechanical characteristics and stability of the joint quality, operating durability and price of the welded rails, production and labour capacity of the process, mechanisation and automation of works.

Mechanical characteristics of welded joints allow making conclusions about the quality and durability of the joints in presence of statistic, dynamic and cyclical loads, determined by means of standard and site-collected specimen. Durability of a welded joint in comparison to a continuous rail both in Latvian and foreign railways is presented in Table 1.

Mechanical characteristics of welded rail

Table 1

\begin{tabular}{|c|c|l|}
\hline $\begin{array}{c}\text { Name of } \\
\text { joint }\end{array}$ & $\begin{array}{c}\text { Durability in omparison } \\
\text { to continuous rail, \% }\end{array}$ & \multicolumn{1}{c|}{ Note } \\
\hline Bolt & $35-40$ & Main welding type used in Russia, Japan \\
\hline $\begin{array}{c}\text { Flash-butt } \\
\text { welding }\end{array}$ & $95-110$ & Used in less intense tracks \\
\hline $\begin{array}{c}\text { Enclosed arc } \\
\text { welding }\end{array}$ & $55-70$ & $\begin{array}{l}\text { Main welding type used in European countries. In } \\
\text { Russia two types of welding are recommended for } \\
\text { the crossing pieces of continuous welded rails, for } \\
\text { welding less intense tracks }\end{array}$ \\
\hline $\begin{array}{c}\text { Alumino- } \\
\text { thermic } \\
\text { welding }\end{array}$ & $65-70$ & $\begin{array}{l}\text { Main welding type in the USA. It has not been } \\
\text { widely adopted in Russia }\end{array}$ \\
\hline $\begin{array}{c}\text { Gas pressure } \\
\text { welding }\end{array}$ & $90-100$ & \\
\hline
\end{tabular}

Flash-butt welding is based on electric power applied between the end faces of the rails being joined and generating flash from large power and low voltage. Flash-butt welding is performed by automated flash-butt welding machines and, according to Table 1, creates one of the most reliable welded joints.

Since 2005, Latvian railway has mainly used rail profile $60 \mathrm{E} 1$ of two manufacturers - Tagyl and Austrian manufacturer "Voestalpine", offering $172 \mathrm{~mm}$ high rail with $72 \mathrm{~mm}$ wide top and $150 \mathrm{~mm}$ wide base [4]. Belorussian and Russian railways also use rail profiles $60 \mathrm{E} 1$, however, the most common in main tracks is the rail profile P-65 manufactured in Tagyl, Azov and Kuznetsk plants. These rails mainly differ in their features: rail profile P-65 is $1800 \mathrm{~mm}$ high, top width is $75 \mathrm{~mm}$ and base width is $150 \mathrm{~mm}$, and it is the heaviest rail type. Rail profile $60 \mathrm{E} 1$ is also one of the heaviest rail types and they correspond to the European standard EN 13674-1:2011 and Russian standard TC 00186269-189-2012 [4].

In 2014 Latvian railway had 40 highly defective rail joints registered, previously repaired with the mobile rail welding machine type No. 4. Number of highly defective rail joints increased in 2015 to 45 cases. Between 2016 and 2017 the number of highly defective welded joints reduced from 16 to 14 cases (Figure 1).

As we know, a fracture of a welded rail joint can result in derail of pair of wheels and also a rolling stock accident. On the basis of statistical data it was decided to study joints welded by means of the mobile rail welding machine type No 4, rail profile 60 E1 T 0608 on running line Menta Taurkalne, $250 \mathrm{~km}, 1 \mathrm{st}$ railway milestone. It turned out that present problem is also topical in other countries. Highly defective welded joints are commonly identified partly in Russian and Belorussian railways "BZhD" [5]. Figure 1 shows a quantitative diagram of highly defective welded joints in Latvian railway.

Latvian railway comprises eight separate tracks. Out of these eight: CDN-1 Šķirotava branch, CDN-2 Čiekurkalns branch, CDN-3 Daugavpils branch CDN-9 Rīga branch, CDN-5 Rēzekne branch, CDN-6 Ventspils branch, CDN-7 Liepāja branch, CDN-8 Jelgava branch. 


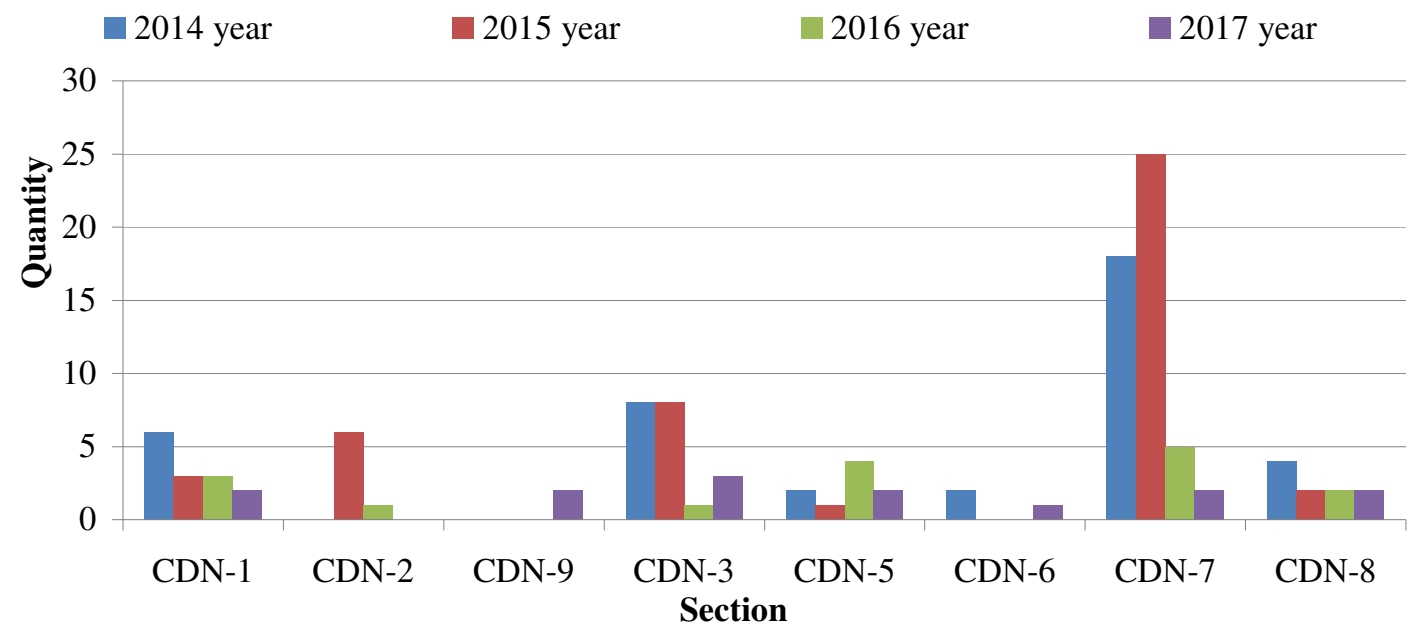

Fig.1. Diagram of highly defective welded joints 2014 - 2017

The following conclusions can be made on the basis of the diagram (Fig. 1): the largest number of welding defects in 2014 was identified in CDN-7 Liepāja branch (18), while in CDN-2 Čiekurkalns branch and CDN-9 Riga branch no defects were found. In 2015 the largest number of defects (25) was still found in CDN-7 Liepāja branch, and in comparison to the year of 2014 it saw increase of 7 defects. In 2015 no defects were established in the welded joints of CDN-9 Riga branch and CDN-6 Ventspils branch. In 2016 the number of welded joint defects decreased partially in CDN-7 Liepāja branch, amounting to merely 5. Similarly as in 2015, also in 2016 no defects in joints welded with the mobile rail welding machine type No 4 were discovered in CDN-9 Riga branch and CDN-6 Ventspils branch. During 2017 the number of identified welded joint defects saw significant drop amounting to merely (3) defects in CDN-3 Daugavpils branch, and no welded joint defects were found in CDN-2 Čiekurkalns branch.

Analysis of statistics on welded joint defects in the railway network of a publicly traded company $\mathrm{RZhD}$ [4] revealed that the largest number of defects is identified under codes 56.3, 66.3, 79.3 and 26.3. Defects under codes 99.3 and 86.3 are also predominant in Russian and Belorussian railways. Quantitative distribution of the welded joint defects (according to defect drawings) in the publicly traded company RZhD is presented in Figure 2.

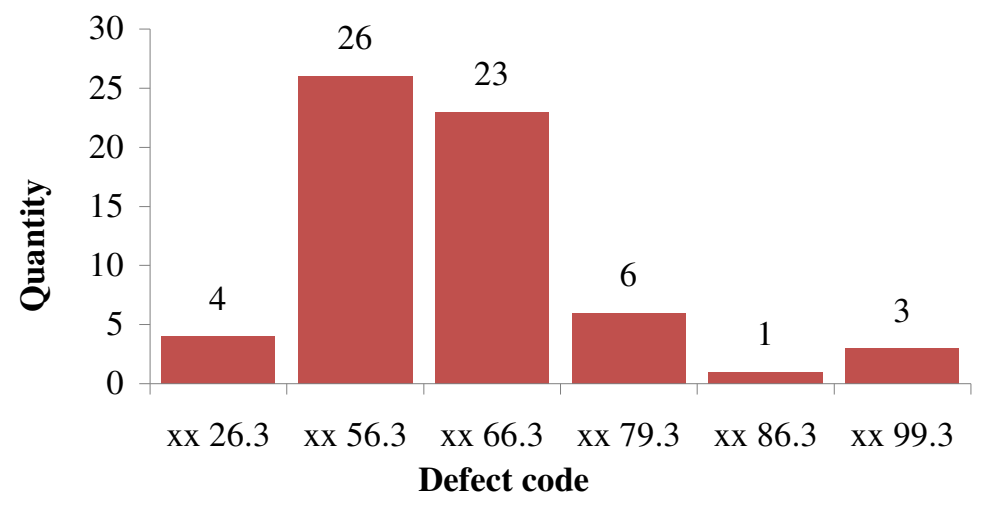

\section{Fig. 2. Quantitative statistics of welded joint defects in network maintained by publicly traded company RZhD}

According to instruction C-010 [1], rail defects, their specifics, classification, catalogue, labelling and train handling on defective and highly defective rails decoding is as follows: the number of crosses on the rail label at all times stands for: $\mathrm{xx}$ - highly defective, $\mathrm{x}$ - defective.

26.3 stands for: - transverse fissures in top due to violation of rail welding technology, digit 3 in all three cases stands for point of flash-butt welding of a joint. 56.3 - fissures in a web in place of old 
welded joint caused by a welding failure or faulty treatment of the welded joint. 66.3 - fissures in the base due to violation of rail welding technology. 79.3 - transverse fracture of rails without visible defects in the fracture. 86.3 - disalignment of rails during welding. 99.3 - other defects and damage of rails and welded joints except aforesaid [1].

Another urgent problem in the Belorussian railway is highly defective rail identified by the inspection shops. Figure 2 shows \% diagram of highly defective rails by groups [5]. Defect groups are as follows:

- group 2 - transversal fissures in the top and resulting fractures;

- group 3 - axial, horizontal and vertical fissures in the top;

- group 5 - web defects and damage;

- group 6 - top defects and damage.

Large part of highly defective rails in "BZhD" network consists of Group 2, amounting to $62.15 \%$ of total amount of flaws identified by the inspection shops of the Belorussian railway [5]. On the basis of classification of C-010 defects of Group 2, these flaws are transversal fissures in the top due to violation of rail welding technology under code 26.3 .

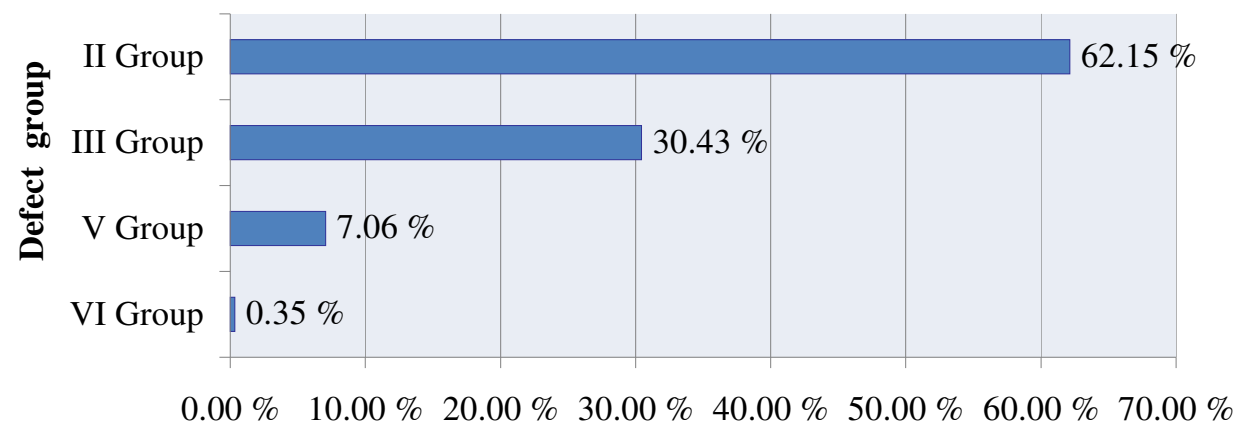

Quantity in \%

Fig. 3. Diagram of distribution of highly defective rails identified by Belorussian railway inspection shops in $\mathbf{2 0 1 5}$

In the process of analysis of highly defective joints welded with the mobile rail welding machine on railway networks a question arises - what is the cause of the said defects? One sign of an emerging defect is low quality rail welding by the mobile rail welding machine or violation of welding technology. On the basis of aforesaid, a decision was made to inspect one join welded with the mobile rail welding machine type No 4 in the Latvian railway. The purpose of it was to analyse the condition of metal in terms of hardness, chemical composition, to determine metal structure and to compare the obtained data with the manufacturer's data.

\section{Materials and methods}

The first stage of analysis took place in the laboratory of the Riga Technical University where the rail steel Brinell hardness was tested with the modern device "Tinius O Olsen" Firmware Version 1.07, FH - 31 Series. Hardness of rail steel was determined as per standards (ISO 6508, ISO 2039/1, ASTM E18, ASTM B254, JIS Z2245). The test results are shown in Fig. 5.

Tread surface of the top: $310,332,392,354,351,352,329,425,430$.

In rail top: $317,295,265,288,299,264,556,576,525,570,268,297,279,311,303,572,533$, $262,271$.

In rail web: 302, 249, 297, 590, 587, 313, 300, 301, 322, 305, 647, 629.

In rail base: 526, 406, 433, 594, 626, 302, 303, 326, 340, 332.

The obtained data were compared to the manufacturer's data [3] as reflected in the table. The results concerning the welding are summed up in Table 2. 


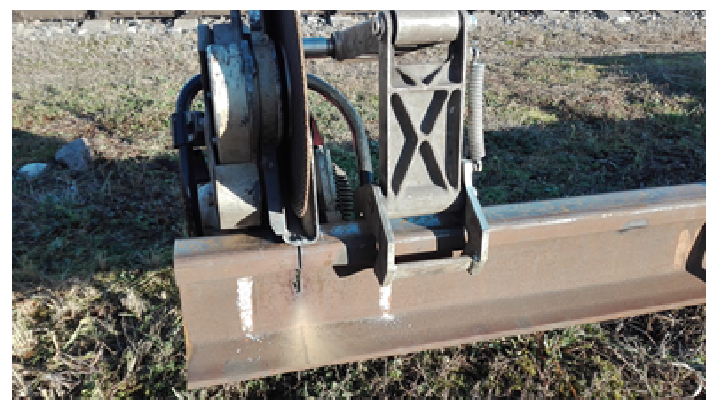

Fig. 4. Process of cutting out piece of welded rail with rail saw

Hardness factor of tread surface of the rail top is even a more important object in rail steel hardness testing. The conducted tests showed that hardness of tread surface of the rail top is $363 \mathrm{HB}$, hence corresponding to the standard (352-405 HB) of the manufacturer's plant.

Average hardness of the welded rail top is $371 \mathrm{HB}$, exceeding the permissible value specified by the manufacturer by $30 \mathrm{HB}$. Testing of the average hardness in the welded rail web indicated at 403 $\mathrm{HB}$ that it exceeds the permissible value specified by the manufacturer by $15 \mathrm{HB}$. On the basis of the obtained results the average hardness of the rail base was $419 \mathrm{HB}$ that exceeds the permissible value specified by the Tagyl plant by $31 \mathrm{HB}$.

\section{Comparison of hardness of the welded rail $60 \mathrm{E} 1 \mathrm{~T}$, steel grade $\mathrm{R350HT}$ with data provided by the manufacturer}

\begin{tabular}{|l|c|c|}
\hline \multirow{2}{*}{\multicolumn{1}{|c|}{ Location of hardness test }} & \multicolumn{2}{c|}{ Label of rail hardness R350HT } \\
\cline { 2 - 3 } & $\begin{array}{c}\text { Hardness specified by } \\
\text { the manufacturer (HB) }\end{array}$ & $\begin{array}{c}\text { Average identified } \\
\text { hardness (HB) }\end{array}$ \\
\hline For tread surface of the top HB & $352-405$ & 363 \\
\hline In the top HB & 341 & 371 \\
\hline In the web, not exceeding & 388 & 403 \\
\hline In the base, not exceeding & 388 & 419 \\
\hline
\end{tabular}

The second phase of testing involved an analysis of the chemical composition of metal in three points of the welded rail (top, web, base). A specimen was cut out with a rail saw from the welded rail joint to be tested. The specimen was polished with a grinding machine to have mirror-like surface (Fig.6).

The chemical composition of metal was determined with the optical emission spectrometer PMI Master PRO, relying on the principle of local burnoff in the specimen's surface followed by determination of the chemical composition and summing up and printing the obtained data [3]. Measurements were done in three different points, three separate times, in the top, web and base of the rail. Average results of the chemical composition analysis of the specimens are presented in Table 3 and Table 4.

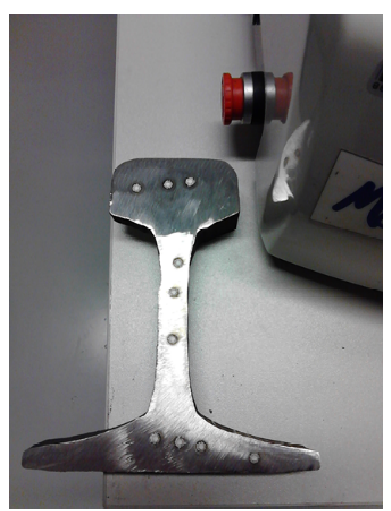

Fig. 6. Determination of chemical composition in three rail components (top, web, base) 
Average - permissible values of the chemical composition in $\%$ of correlation of the tested welded rail (top, web, base) profile 60 E1 T 0608

\begin{tabular}{|c|c|c|c|c|c|}
\hline Value & Max / Min & ToP & WEB & BASE & AVERAGE \\
\hline $\mathbf{F e}$ & - & 97.7 & 97.6 & 97.7 & 97.7 \\
\hline $\mathbf{C}$ & \pm 0.02 & 0.76 & 0.787 & 0.767 & 0.771 \\
\hline $\mathbf{S i}$ & \pm 0.02 & 0.351 & 0.371 & 0.36 & 0.361 \\
\hline $\mathbf{M n}$ & \pm 0.05 & 0.897 & 0.927 & 0.929 & 0.917 \\
\hline $\mathbf{P}$ & 0.005 & 0.0346 & 0.0368 & 0.0394 & 0.0369 \\
\hline $\mathbf{S}$ & 0.005 & 0.0173 & 0.0171 & 0.0187 & 0.0177 \\
\hline $\mathbf{C r}$ & \pm 0.02 & 0.0293 & 0.0315 & 0.029 & 0.0299 \\
\hline $\mathbf{M o}$ & - & 0.003 & 0.003 & 0.003 & 0.003 \\
\hline $\mathbf{N i}$ & - & 0.0327 & 0.0364 & 0.0349 & 0.0346 \\
\hline $\mathbf{A l}$ & 0.001 & 0.0066 & 0.0078 & 0.0066 & 0.007 \\
\hline $\mathbf{C o}$ & - & 0.0305 & 0.0317 & 0.0305 & 0.0309 \\
\hline $\mathbf{C u}$ & - & 0.0112 & 0.0129 & 0.0121 & 0.0121 \\
\hline $\mathbf{N b}$ & - & 0.003 & 0.003 & 0.003 & 0.005 \\
\hline $\mathbf{T i}$ & - & 0.002 & 0.0023 & 0.002 & 0.0021 \\
\hline $\mathbf{V}$ & 0.02 & 0.0385 & 0.0403 & 0.0392 & 0.0393 \\
\hline $\mathbf{W}$ & - & 0.025 & 0.025 & 0.025 & 0.025 \\
\hline $\mathbf{P b}$ & - & 0.01 & 0.01 & 0.01 & 0.001 \\
\hline $\mathbf{Z r}$ & - & 0.003 & 0.003 & 0.003 & 0.003 \\
\hline
\end{tabular}

Table 4

Table showing the average values (in percent) of chemical composition specified by the manufacturer's plant in Tagyl with rail profile $60 \mathrm{E} 1 \mathrm{~T}$

\begin{tabular}{|c|c|c|}
\hline Value & MAX / MiN & AVERAGE \\
\hline $\mathbf{C}$ & \pm 0.02 & 0.766 \\
\hline $\mathbf{M n}$ & \pm 0.05 & 0.963 \\
\hline $\mathbf{S i}$ & \pm 0.02 & 0.36 \\
\hline $\mathbf{P}$ & 0.005 & 0.011 \\
\hline $\mathbf{S}$ & 0.005 & 0.01 \\
\hline $\mathbf{C r}$ & \pm 0.02 & 0.0367 \\
\hline $\mathbf{N i}$ & - & 0.0483 \\
\hline $\mathbf{C u}$ & - & 0.0083 \\
\hline $\mathbf{A l}$ & 0.001 & 0.0026 \\
\hline $\mathbf{V}$ & 0.02 & 0.0393 \\
\hline $\mathbf{N}$ & $\pm 0,005$ & 0.00457 \\
\hline $\mathbf{H}, \mathbf{p p m}$ & - & 1.3 \\
\hline $\mathbf{O 2}$ & - & 0.0012 \\
\hline
\end{tabular}

When testing the chemical composition of the welded joint steel in the Riga Technical University lab the following discrepancies were established [2]. In the manufacturer's passport data the following chemical elements were not specified: (Mo) molybdenum - increases red hardness, elastic behaviour, ultimate tensile strength, rust prevention and high-temperature oxidation resistance, (Co) cobalt increases heat stability, magnetic behaviour, increases shock resistance, $(\mathrm{Nb})$ niobium - improves acid resistance and promotes rust reduction in the welded constructions, (Ti) titanium - improves steel strength and density, promotes grain refining, serves as efficient deoxidizing agent, improves working properties and rust prevention, $(\mathrm{V})$ vanadium - increases hardness and strength, refines grain. As an efficient deoxidizing agent it increases steel density, (W) wolfram - forms very strong chemical compounds in steel - carbides, thus significantly increasing hardness and red hardness. Wolfram prevents grain formation during heating, allows eliminating fragility while softened, $(\mathrm{Pb})$ lead accidental steel impurity, ( $\mathrm{Zr}$ ) zirconium - has a special impact on the size and formation of grain in 
steel, it refines the grain and yields the steel with a predetermined graininess [1]. Comparison with the main, permissible values of the chemical elements forming the rail steel is given in Table 2 and Table 3. Carbon (C) content is present within the permissible limits and amounts to $0.771 \%$. Results of the tests show that manganese $(\mathrm{Mn})$ content also falls within a range and amounts to $0.917 \%$. Chemical element silicon $(\mathrm{Si})$ corresponds to the permissible percentage radio and amounts to $0.361 \%$. Chrome (Cr) content also lies within the standard range of values and equals $0.0299 \%$ [6]. Percentage of content of such chemical elements as phosphorus (P) and sulphur (S) exceeds the permissible \% values in insignificant amounts. Percentage of phosphorus (P) exceeds the range by $0.0209 \%$ while percentage of sulphur (S) exceeds the range merely by $0.0027 \%$. Percentage value of chemical element such as nitrogen $(\mathrm{N})$ was not established in tests. Aluminium $(\mathrm{Al})$ content exceeds the range by $0.0043 \%$.

Conducted tests allow determining rail steel hardness, chemical composition of steel, mass fractions of metal elements and provide an answer about the quality of joints welded with the mobile rail welding machine type No 4 .

The third phase of the study determined the rail steel structure with a modern electron microscope Carl Zeiss Axiovert 40 MAT, and the obtained data were entered in computer. Before determining the metal structure, the specimen's surface was corroded with $5 \%$ solution of the nitric acid $\mathrm{HNO}_{3}$ [1]. The structure of the first specimen was determined under the microscope at magnification (x50) and (x200) without corroding the metal. The second specimen was analysed at magnification (x50), (x200) and (x500), and was corroded.

The obtained test data are reflected in Fig.8 and Fig.9 and they allow us to draw the main conclusions about the quality of rail steel welded with the mobile rail welding machine. The obtained data show small impurities as black spots in the metal structure. It also confirms presence of insignificant amounts of phosphorus and sulphur in the tested chemical composition. When comparing the metal structure at magnification x 50 (a), x 200 (b) and x 500 (c), insignificant amounts of different impurities are discovered. The structure of present metal is ferritic. Ferritic structure includes compound of ferrous oxide $\mathrm{Fe}_{2} \mathrm{O}_{3}$ with more basal oxides of others metals that are ferrimagnets, the base component of iron alloys, presented in the solid carbon solution and alloying elements. It has a volume-centric cubic crystalline grid. It is a phase component of other structures, for example, perlite, comprised of ferrite and ferric carbide. If the temperature exceeds $1401{ }^{\circ} \mathrm{C}$ in iron-carbon metal it forms solid carbon solution that can be considered as delta ferrite.

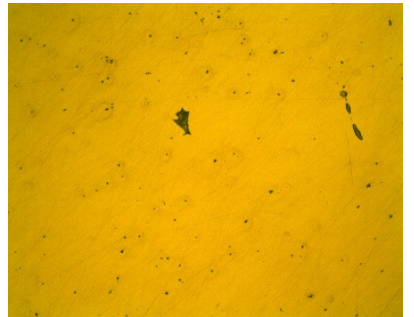

a) Magnification $x 50$

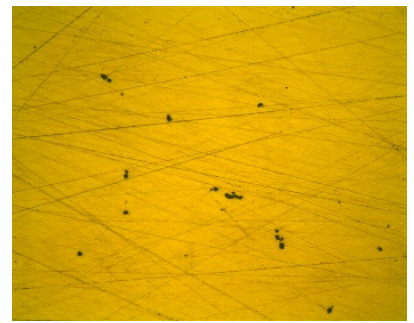

b) Magnification x 200

Fig. 8. Determination of metal structure under microscope at various magnifications

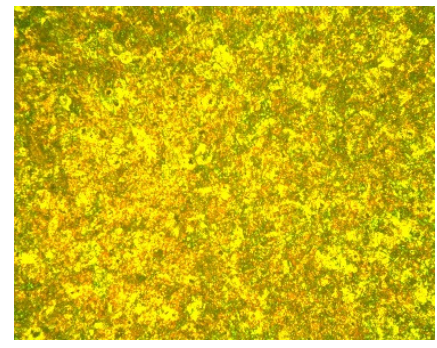

a) Magnification $x 50$

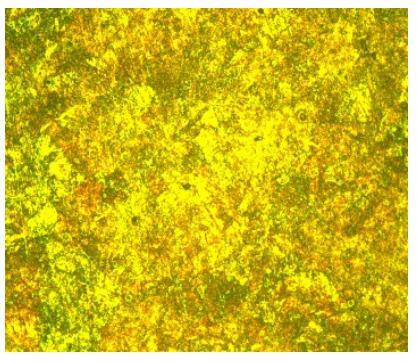

b) Magnification x 200

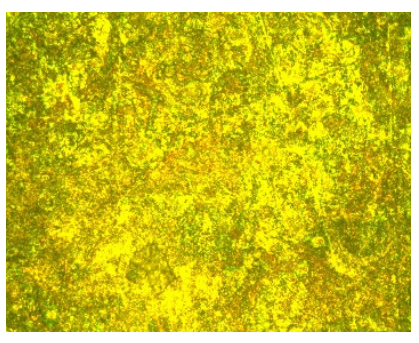

c) Magnification $x 500$

Fig. 9. Determination of metal structure under microscope, corroded with nitric acid $\left(\mathrm{HNO}_{3}\right)$ and at different magnification 


\section{Results and discussion}

From the foreseen research it is possible to sum up the following results and reasoning.

When determining the hardness of the welded joint, compliance with the factory standard EN 13674-1: 2011 was established. Hardness indices in the head, neck and sole have superior factorystandard parameters by an average of $25.33 \mathrm{HB}$. This indicates the quality of the welded joint. The results obtained are valid because hardness was rechecked by the firm "Krautkamer", which confirmed the results.

The chemical composition determination using the PMI-Master PRO optical emission analyzer, which was calibrated and tested on analogous samples of welded joints with the confirming specification of the instrument and samples, was performed before the start of the research process. In the process of investigation it was established that the content of such basic chemical elements as $\mathrm{C}$, Mn, Si, Cr fully comply with the standard EN 13674-1: 2011, with a slight habit of P and S.

The structure of the rail steel is ferrite with small inclusions of the form of dark spots. Perhaps, these are the harmful impurities of sulfur and phosphorus, which also confirms the study of the chemical composition. Such a definition of the metal structure is established and defined in different countries of the world in particular the USA, Lithuania, and Estonia.

\section{Conclusions}

1. This scientific research article has attained its main objective - analysis of hardness, chemical composition and determination of metal structure of a welded joint of Tagyl rail profile $60 \mathrm{E} 1$, performed with the mobile rail welding machine, and comparison of the obtained data with the manufacturer's plant standards.

2. The steel of a joint welded with the mobile rail welding machine was tested for its Brinell hardness (HB) by means of a modern device "Tinius O Olsen" Firmware Version 1.07, FH - 31 Series. The obtained data were compared to the passport data provided by Tagyl plant of the manufacturer.

3. Hardness of the tested joint welded with the mobile rail welding machine type No 4 corresponds to the standard (EN 13674-1:2011) set forth by Tagyl plant of the manufacturer.

4. Results of the hardness test of steel R350HT: on the tread surface (363 HB), on the top (371 HB), in the web $(403 \mathrm{HB})$ and the base $(419 \mathrm{HB})$ indicates at good quality welding of the joint welded with the mobile rail welding machine type No 4 .

5. After studying the chemical composition (top, web, base) it was established that the contents of elements such as carbon $(\mathrm{C})$, manganese $(\mathrm{Mn})$, silicon $(\mathrm{Si})$, chrome $(\mathrm{Cr})$ comply with the applicable standards (EN 13674-1:2011) of the manufacturer's plant.

6. It was established that the percentage content of phosphorus (P) and sulphur (S) is insignificantly elevated. Phosphorus by $0.0209 \%$ and sulphur by $0.0027 \%$.

7. Small impurities as black spots have been detected in the metal structure; it can be assumed that these are admixture of phosphorus and sulphur having no significant impact on the quality of the welded joint.

8. The study led to answers about the quality of the joint welded with the mobile rail welding machine type No 4, and confirmed the compliance: according to metal hardness, chemical composition and metal structure.

\section{References}

[1] Baiko S. Latvian railway SJSC Service of railway equipment. Confirmed Latvian railway SJSC First deputy of CEO Norms and specifications book for defective rails NTD-S-97. Riga, 1997, pp. 14-41.

[2] Korostelev P.P. Reagents for technical analysis, 1988, 104 p.

[3] Mihailovs, F.Sansyzbajeva, Z. Mezitis, M. Journal Simulation of the Interaction of Railway Station and Harbor. Procedia Computer Science Volume 104, 1 December 2016, ICTE 2016; Riga Technical University Riga; Latvia; Code 134528, ISSN: 18770509, 2016, pp. 222-226. DOI: $10.1016 /$ j.procs.2017.01.117

[4] Sergejevs D., Tipainis A. Assessment of railway turnout element restoration using MMA and FCAW welding. Latvia University of Agriculture Faculty of Engineering. 15th International 
Scientific Conference Engineering For Rural Development Proceedings, Volume 15 Jelgava,25.27.05.2016. ISSN1691-5976. pp. 606-611.

[5] Strautmanis, G., Mezîtis, M., Strautmane, V. The Impact of Rotor Elastic Suspension Settings on the Acceleration of the Automatic Balancer Compensating Mass. Vibroengineering Procedia, 2017, Vol.14,.lpp. ISSN 2345-0533. Pieejams: doi:10.21595/vp.2017.18306. pp. 13-17.

[6] ЕВРА3. Form 3. Export. СДС ОПЖТ RU.В.0020 24.08.2011 г. Quality Certificate Nr. 3094. Rails type 60 E1 Section class Y.Straightness B. EN 13674-1:2011, TC 00186269-189-2012.

[7] Шляхтенок А.В., канд. техн. наук, доц. Д.А. Довгяло. (Полоцкий государственный университет) 2016. Вестник Полоцкого Государственного Университета. Фундаментальные Науки. Физика. Серия С “Ультразвуковая Рельсовая Дефектоскопия" УДК 681.586.773:624.072.233.5. pp.64-70.

[8] Merkulov T., Rozdestvenskiy S., Rukavchuk J., Shelukhin A., Etingens I. OAО «ВНИИЖТ» при участии специалистов ИЦ «Про-безопасность». Журнал «Путь и путевое хозяйство» №11 за 2013 г. Российские железные дороги (Москва) “Анализ системы неразрушающего контроля сварных стыков рельсов”. ISSN: 0131-5765. p. 6-9.

[9] Tatarinovs, A., Mironovs, V., Rybak, D., Stankēvičs, P. Non-Destructive Testing of Joints of Antifriction Parts Crimped by Pulsed Magnetic Deformation. Solid State Phenomena, 2017, Vol.267,. ISSN 1662-9779. Pieejams: doi:10.4028/www.scientific.ne. pp. 248-252. 